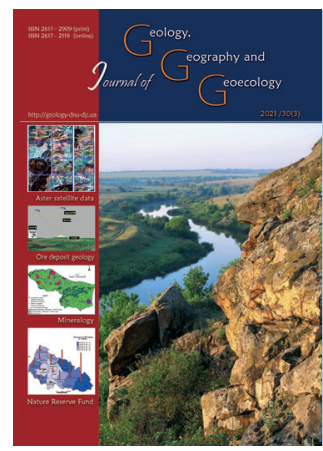

\section{Journal of Geology, Geography and Geoecology}

Journal home page: geology-dnu.dp.ua
ISSN 2617-2909 (print)

ISSN 2617-2119 (online)

Journ. Geol. Geograph. Geology, 30(3), 581-588.

doi: $10.15421 / 112153$

Tagiev I. I., Paşayev N. V., Karimov V. M.

Geol. Geograph. Geoecology, 30(3), 581-588

\title{
Volcanic and fault-fractured ore-controlling structures and minerals of the Azerbaijan part of the Lesser Caucasus
}

\author{
Islam I. Tagiev, Namat V. Paşayev, Vagif M. Karimov \\ Azerbaijan State University of Oil and Industry, Azerbaijan Republic, Baku, e-mail: vagifkerimov1968@gmail.com,
}

Received: 01.03.2021

Received in revised form: 21.04 .2021

Accepted: 04.08.2021

Abstract.This article is focused on volcanic and fault-fissure ore-controlling structures of the Lesser Caucasus. The territory of the Lesser Caucasus is dissected by many deep tectonic faults, along which volatile compounds of postmagmatic products and water vapor migrate from great depths. The presence of numerous tectonic deep faults, which provide hydrodynamic connection of waters of fracturse, and fracture-veins, determines the complex mineralization of the chemical and gas composition of mineral-thermal waters throughout the studied area. The study of volcano-intrusive and fault-fracture ore-controlling structures, volcanogenic formations, petrochemical composition of rocks and associated mineral deposits and mineral-thermal waters of the Azerbaijan part of the Lesser Caucasus is relevant from a scientific and practical points of view. A detailed study of the modern structure of the Lesser Caucasus shows that transverse rupture faults and deep flexures cut through the folded system. Deposits of various minerals, including mineral and thermal waters, are confined to these ruptured faults. The study revealed that the formation and discharge of numerous outcrops of carbonic mineral and thermal waters occurs mainly in fissure systems, in deep tectonic faults. In the Lok-Karabakh zone, most of the sources of the formation of gold-bearing placers belong to the deposits and manifestations of the goldquartz-low-sulphide formation. Gosha, Kedabek, Karadag, Chovdar, Dagkesemen, Gyzylbulag and less significant deposits and ore occurrences are located in this zone. The Dashkesan ore region is distinguished by the reserves of iron, alunite and cobalt. The Zaylik alunite deposits are world famous in terms of large reserves. Analysis of geological materials confirms that the origin and distribution of deep tectonic faults plays a major role in the formation of geological, including volcanoplutonic, metamorphic processes and associated ore formation. Currently, there are dozens of variously evaluated and explored gold deposits on the territory of the Republic. The bulk of the primary deposits are located in the Lesser Caucasus part of the Republic.

Keywords: volcanism, minerals, gold deposits, mineral and thermal waters.

\section{Вулканічні і розломно-тріщинні рудоконтролюючі структури i корисні копалини Азербайджанської частини Малого Кавказу}

\section{I. Тагієв, Н. В. Пашаєв, В. М. Керімов} Азербайджанський держсавний університет Нафти і Промисловості, Азербайджанська республіка, Баку,
vagifkerimov1968@gmail.com

Анотація. Дана стаття присвячена вулканічним і розломно-тріщиним рудоконтролюючим структурам Малого Кавказу. Територія Малого Кавказу розсічена безліччю глибинних тектонічних розломів, по яких мігрують леткі сполуки постмагматичних продуктів і водяні пари, що надходять з великих глибин. Наявність численних тектонічних глибинних розломів, по яких відбувається гідродинамічний зв'язок тріщинних, тріщинно-жильних вод, зумовлює строкату мінералізацію хімічного і газового складу мінерально-термальних вод по всій досліджуваній площі. Вивчення вулкана-інтрузивних і розломнотріщинних рудоконтролюючих структур, вулканогенних формацій, петрохимичного складу порід і пов'язаних з ними родовищ корисних копалин, мінерально-термальних вод Азербайджанської частини Малого Кавказу є актуальним 3 наукової та практичної точки зору. Детальне вивчення сучасної структури Малого Кавказу показує, що поперечні розривні порушення та флексури глибокого закладення розтинають складчасту систему. До цих розривних порушень приурочені родовища різних корисних копалин, в тому числі мінерально-термальних вод. З'ясовано, що формування і розвантаження численних виходів вуглекислих мінеральних і термальних вод відбувається переважно в тріщинних системах, в глибоких тектонічних розломах. В Лок-Карабаській зоні велика частина джерел формування золотоносних розсипів належить до родовищ і проявів золотокварцово-малосульфідної формації. У цій зоні розміщені Гошінске, Кедабекське, Карадазьке, Човдарськей, Дагкесеменське, Гизилбулагське і менш значущі родовища і рудопрояви. Дашкесенскій рудний район виділяється за запасами заліза, алуниту і кобальту. Всесвітньо відоме за величиною запасів Зайлікське родовище алунітів. Аналіз геологічних матеріалів підтверджує, що походження і закономірність поширення глибинних тектонічних розломів відіграє основну роль у формуванні геологічних, в тому числі вулканоплутонічних, метаморфічних процесів і пов'язаного з ним рудоутворення. В даний час на території республіки нараховуються десятки різного ступеня оцінених і розвіданих золоторудних родовищ. Основна кількість корінних родовищ розміщені в Малокавказькй частини республіки. 
Ключові слова: вулканізм, корисні копалини, золоторудні родовища мінеральні і термальні води.

\section{Introduction.}

The Azerbaijanian part of the Lesser Caucasus is a complex system of mountain ranges and volcanic uplands, different from the Major Caucasus by lower absolute altitudes and insignificant manifestation of contemporary glaciation. The area of the Lesser Caucasus is mostly tectonic-denudation terrain with dense erosion and deep fracturing.

The Lesser Caucasus is characterized by the development of volcanogenic formations (from Upper Paleozoic to Quaternary periods), bent in the gently sloping folds of latitudinal in the West and Caucasian in the South-East strike. There are distinct tectonic zones composed of carbonate and volcanogenic rocks of Cretaceous period and tufagenic-volcanogenic rocks of Paleocene and Eocene age, accumulated in the latitudinal riftogenic depressions (Abdullaev, et al., 1991; Mustafaev, et al., 2011).

Within the Lesser Caucasus, the Lok-Karabakh, Geicha-Akera, Miskhan-Kafan structural-formation zones are designated (Geologiya Azerbajdzhana, 2005). The Talysh structural-formation zone is confined to the northeast border of the Lesser Caucasus-Elburz folded system and is an isolated horst that submerges under the Neogene-Quaternary deposits of the Lower Araz depression in the northwest and the Quaternary deposits of the Kura fault in the northeast (Geologiya Azerbajdzhana, 2001).

By age, the Mezozoic magmatic formations of the Lesser Caucasus are identified to the Middle-Jurassic, Upper Jurassic-Lower Cretaceous, Lower Cretaceous and Upper Cretaceous periods.

Broadly distributed deposits in the Lesser Caucasus are of the Paleozoic Era, the oldest being those of the Emsian stage of the Lower Devonian period. Those are metamorphic slates, silicified limestones, dolomites, quartzites, sandstones, argillites and clayey slates. The thickness of the deposits is over 1,200 m. The Jurassic deposits in the area comprise highland and middlemountainous zones. The Lower Jurarassic is represented by clayey and clayey-sandy slates, aleurites, sandstones. The Middle and Upper Jurassic epochs are manifested by volcanic, volcanogenic-sedimentary and sedimentary facies of over 3,000 $\mathrm{m}$ thickness.

\section{Materials and methods.}

The article uses the results of field and laboratory surveys performed by the authors. We also used published and fund materials of various authors working in the Republic. We performed typing of the ore and hydro-mineral resources of the studied area and characterized their chemical composition and medical properties of mineralized waters.

\section{Discussion.}

The Lok-Karabakh zone within the Republic is located on the eastern slope of the Lesser Caucasus and is characterized by richness and diversity of ore and hydromineral resources. Especially notable are the waterways of the territory, represented by the Aghstafa, Hasansu, Tovuzchay, Dzegamchay, Chagirchay, Shamkirchay, Ganjachay Rivers.

In the basins of those rivers, gold-bearing placers have been discovered. Most of the sources of development of gold-bearing placers belong to the deposits and manifestations of gold-quartz-low-sulfide formation and are represented by steeply dipping veins of chiefly quartzitic composition and also zones of hydrothermally altered rocks mostly belonging to the facies of secondary quartzitic metasomatites.

Given that all other conditions are equal, the possibility of existence of a placer depends on the proportion between individual links of denudational morphosystems promoting the formation of placer (Fig. 1).

Based on paleogeographic analysis, the conclusion is that in the epoch of formation of gold-bearing alluvial layers embedded in the basis of the section, the climate was continental, and the physical weathering that mostly forms large-fragment alluvium dominated. The Lesser Caucasus is also rich in various genetic types of gold ore deposits such as Soyutlu, Gizil Bulag (Kalbajar District), Vejnali (Zangilan District), Gosha, (Tovuz District), Kedabek (Kedabek District), Dagkesaman (Qazakh District), Piyasbashi (Ordubad District) (Babazade, 2003).

The Shamkir Upland, where the Gosha goldpyrite deposits are located, is a large structure of sublatitudinal strike. Its structure is composed of mostly Middle Jurassic volcanogenic formations, torn by Upper Bajocian granitoid intrusive complexes.

The Gosha gold-pyrite deposits are typical representatives of volcanogenic deposits with progressive ore-formation and are connected with the continuous basalt-andesite-rhyolite formation, localizing in the vault part of the sub-volcanic structure. The deposits are characterized by the confinement to the local regional-dome structure of the Jurassic age, where the central place belongs to the volcanic-tectonic structure held by the intersection of large regional faults of northwest, sub-meridian and sub-latitudinal strikes (Mansurov, et al., 2018).

Besides the Gosha deposits, within the LokKarabakh zone, there are Kedabek, Chovdar, Dagkesemen, Gyzylbulag and less significant deposits, where ore has been developed as a result of the activity 
of magmatic systems which had occurred in the Middle-

Late Mezozoic Era.

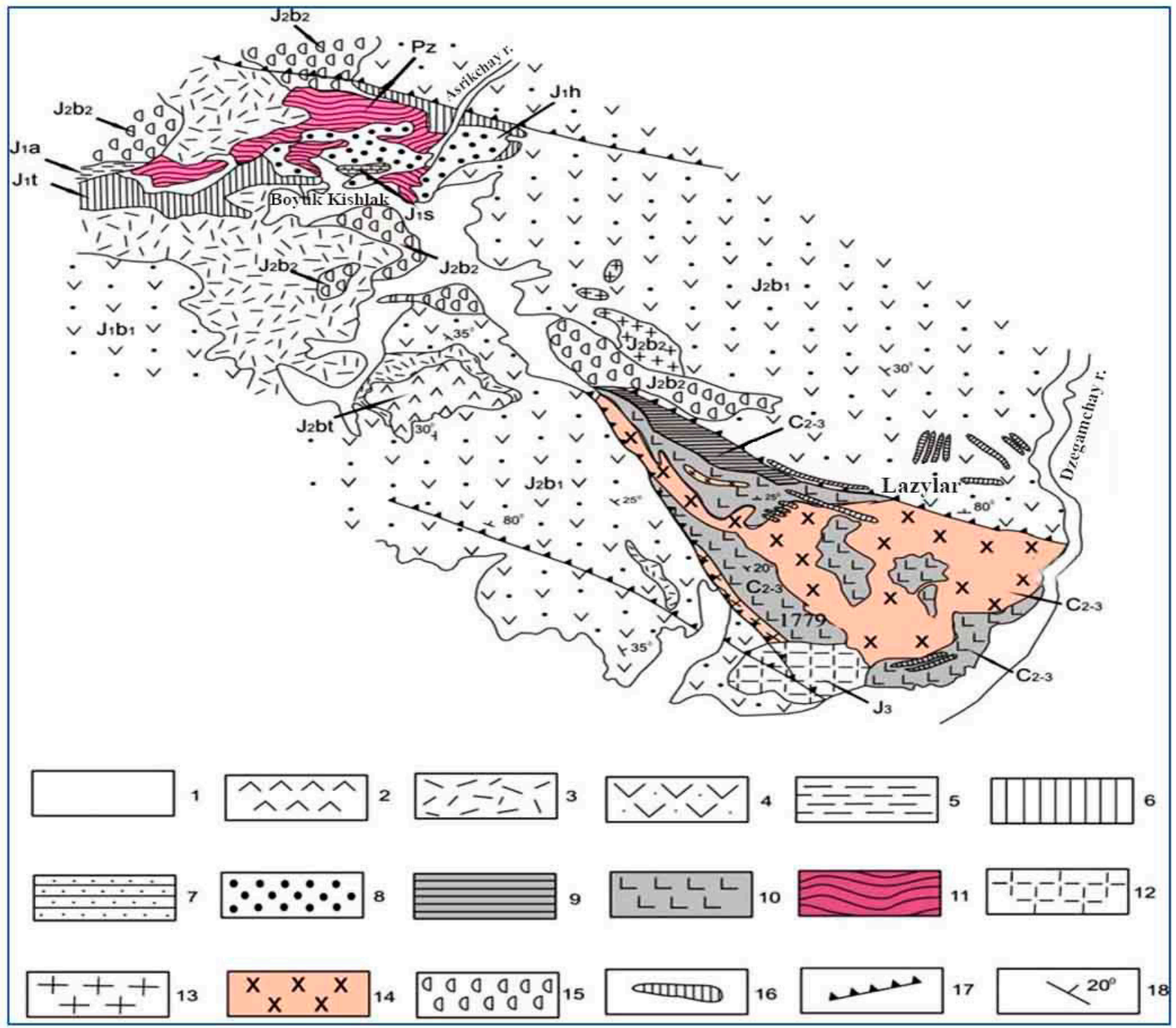

Fig. 1. Schematic geological map of the interfluves between the Dzegamchay and Asrikchay

1-contemporary and Upper Quaternary deposits, alluvial and alluvial-prolluvial: loams, loamy sand, pebble stones, boulders; 2- Bathonian stage: plagioclase and pyroxene porphyrites, lava breccias, volcanic breccias and tuffites; 3-Upper Bajocian sub-stage: agglomerate lava flows, tufa, tuffites, tufa-breccias of rhyolite and rhyolite-dacites with interlayers of tufa sandstones, tufa gravelites and tufa; 4-Lower Bajocian sub-stage: agglomerate lavas, lava breccias, tufa conglomerates, tufa breccias, diabase flows, rarer andesites, which transform into patches of tufogenic sandstones, aleurites, tufa and tufa gravelites; 5- Aalenian stage: sandy-clayey slates and tufa sandstones; 6- Toarcian stage: clayey slates, slatelike and thin platy aleurites that contain concretions of ash tufa and tufa-aleurites; 7-Sinemurian stage: sandstones with tufa inclusions and interlayers of limestones; 8-Hettangian stage: basal conglomerates with layers of quartzitic sandstones, rarer clayey slates; 9-Middle and Upper Carbon: tuff-sedimentary layer: alternation of tuffites, tufa aleurites, aleurites, clayey slates and sandstones; 10-Middle and Upper Carbon: volcanic layer, alternation of different-sized fragmented tuff of intermediate - basic composition with thin interlayers of aleurites and clayey slates; 11- Eopaleozoic: micaceous-chlorite, sericite clayey, siliceous, quartzitic, clayey-graphite slates; Intrusive formations: 12-Upper Jurassic granitoides and quartzitic diorites; 13-Upper Bajocian plagiogranites; 14-Upper Paleozoic stratum injections of syenite-diorites. Subvolcanic and vein formations: 15-Upper Bajocian rhyolites, rhyolite-dacites; 16-dikes of diabases and andesites; 17-regional faults; 18-elements of embedding of the rocks.

The Dashkesan ore district is notable for reserves of iron, alunite and cobalt. The Dashkesan iron ore deposits have provided iron concentrate to the Rustavi Metallurgical Plant in Georgia for a long time.
Globally recognized as the one having greatest deposits of alunites, the Zeylik deposits of alunite provide raw material for obtaining aluminum in the aluminum industry, as well as obtaining sulfuric acid and 
fertilizers. Aluminum ore may be annually processed to 200 thou tones of agloporite (sintered fly ash), a light concrete.

The Dagkesaman gold ore deposits are confined to the Kazakh depression of the Lok-Karabakh structuralformation zone of the Lesser Caucasus. The geological structure is composed of a complex of sedimentarypyroclastic effusive and subvolcanic rocks of the Cretaceous and Paleogene-Neogene periods. The main folded structure of the deposits is an anticline fold of the same name, belonging to the northeast strike. In the pre-axis part of the fold, there are outcrops of the albitophyre and rhyodacite bodies and the ramifications of the Agdam-Rivazlin fault which were the canals for the inflow of the ore-bearing hydrothermal fluids and sedimentation of the ores in the newly-formed mineralized zones, the number of which is more than ten, including the three main zones.

Within the volcanogenic upland, clearly manifested the Gosha gold-pyrite deposits are some of the most promising objects of the Kedabek mining district. The ore bodies are of the vein-impregnation type.

Complex geological-structural conditions of the region, in which there are signs of recent powerful volcanic processes, have led to a vast amount (over 50 mineral sources) of mineral waters with various conditions of the circulation. Formation and discharge of numerous seeps of carbon dioxide mineral and thermal waters mostly take place in fractured systems, in deep tectonic faults (Mustafaev, et al., 2011).

The Geicha-Akera folded region is a synclinorium oriented northwest, which is in the central part of the Lesser Caucasus, where there are numerous derivatives of intrusive and effusive magmatism, especially the Quaternary lava complex that is significant in the formation of mineral and thermal waters. In this region, there have been studied over 300 sources united in four zones: İstisu-Kalbajar, Turshsu-Shırlan, MinkendAhmedli and Lok-Agdam (Geologiya Azerbajdzhana, 2005).

The İstisu-Kalbajar zone has a complex geological structure caused by greater diversity of the sedimentary, volcanogenic-sedimentary, volcanogenic and intrusive rocks. Tectonically, it is included in the Kalbajar basin fold that is one of the main elements of the central part of the meganticlinorium of the Lesser Caucasus. The geological section of the sediments, which is included in the Kalbajar synclinorium of the Lesser Caucasus, covers the Cretaceous - Anthropogenic interval with some breaks.

Cretaceous sediments in the upper reach of the basin of the Terter River have a relatively limited distribution. They are ruptured by numerous intrusive hyperbasites that make up the ophiolite belt of the Lesser Caucasus, represented by thick sedimentary, volcanogenic-sedimentary and volcanogenic rocks.

Paleogenic sediments with thickness of 1,500 m and more are mainly distributed within the Kalbajarİstisu synclinorium belt, especially in its central part, in the sites of the Shurtan, İstisu, Zeylik, south of villages Chirag, Keshtek and others.

Neogene sediments are quite broadly distributed and represented by andesites, andesite-dasites and their pyroclastic sediments of up to $1,400 \mathrm{~m}$ thickness, chiefly on the left bank of the Terter River. This indicates that the centers of flows of the volcanoes of this period were located along the current valley of the Terter River.

A distinctive trait of the volcanites of the Later Miocene-Lower Pliocene age in the Lesser Caucasus is that they are mainly composed of the of the intermediate and acidic composition of pyroclastic and effusive formations. The volcanism is mainly represented by andesites, trakhyandesites, dasites, trakhydasites and rhyolites (Imamverdiev, 2000; Imamverdiev, et al., 2020).

In the İstisu area (Kalbajar district), numerous dikes of rhyolites and andesite-dasites are seen, indicating broad distribution of deep tectonic faults.

Within the Geicha-Akerin zone, there are goldore (Soyudlu - Zod, Agduzdag) and mercury deposits (Shorbulag, Aggaya, Levchay and others).

The discovery of the Zod-Soyudlu gold ore deposits (Kalbajar district of Azerbaijan and Basarkecher district of Armenia) was a powerful stimulus to carrying out specialized searches for gold in the Lesser Caucasus. These searches led to discovery of a number of deposits of gold and rich gold and silver-bearing ores (Baba-zade, 2003).

Note: From 1970-1980, a detailed survey of the Zod-Soyudlu deposits was conducted and the industrial reserves were assessed as $89 \mathrm{t}$ of gold and $145 \mathrm{t}$ of silver, and since 1976 they have been illegally exploited by the Republic of Armenia. Out of 23 ore veins, only 7 are located in the Basarkecher district (Armenia). This issue has its own history, and we consider that there is no need to describe it in detail in the scientific article.

In the upper reaches of the Terter River, it has long been known that there are numerous sources of carbon dioxide-containing mineral water with various temperatures (Table 1). They are mainly localized in shallow faults, which support the regional ones, and the thermal sources are usually confined to deep faults and faults of average depth. By the chemical composition and medicinal properties, these waters are identical to the globally famous sources Karlovy Vary in the Czech Republic, Germany, Zheleznovodsk in Russia. 
Table 1. The main parameters of deposits of mineral waters of Kalbajar district of the Lesser Caucasus (Bank of the regional data)

\begin{tabular}{|c|c|c|}
\hline № & The main parameters & Geological-hydrogeological data \\
\hline 1 & Name of the deposits & Upper İstisu (Kalbajar district) \\
\hline 2 & Types of minerals & Carbonaceous $-\mathrm{CO}_{2}$ - thermal waters \\
\hline 3 & $\begin{array}{l}\text { Geographical coordinates and } \\
\text { locations of the deposits }\end{array}$ & $\begin{array}{l}\text { In the Upper Reach of the Terterçay, at the distance of } 20 \mathrm{~km} \text { southwest of } \\
\text { Kalbajar district }\end{array}$ \\
\hline 4 & $\begin{array}{c}\text { Types, age and geologic-lithologic } \\
\text { composition and other parameters of } \\
\text { aquatic resources }\end{array}$ & $\begin{array}{l}\text { The deposits are confined to volcanogenic layer of the Middle Jurarassic period. } \\
\text { There are } 6 \text { wells of } 365-700 \mathrm{~m} \text {, exposed by thermal waters of the temperature } \\
\text { of } 70^{\circ} \mathrm{C} \text {, flow rate of } 44-400 \mathrm{~m}^{3} / \text { day, overall discharge (flow rate) }-3,200 \mathrm{~m}^{3} / \text { day. } \\
\qquad \mathrm{HCO}-50 \% \text { - equiv; } \mathrm{Ca}-8 \% \text { - equiv; } \\
\mathrm{Na}-40 \% \text { - equiv; } \\
\qquad \mathrm{Cl}-34 \% \text { - equiv; } \quad \mathrm{M}-4.4-7.6 \mathrm{~g} / \mathrm{L}\end{array}$ \\
\hline
\end{tabular}

The Turshsu-Shirlan zone is located in Shirlan district in the border zone of the eastern part of the Lesser Caucasus. The main reason for discharge of the mineral water in the Turshsu-Shirlan zone is the thrust fault line of the Lesser Caucasus. Fragmentation and folds on the Mezozoic layers in the indicated region are represented by three ramifying thrust fault lines, one being along the border between the Middle Jurassic volcanogenic and Lower Cretaceous layers, the second one on the border of the Tithinian limestones, and the third on the ultra-basic rocks in which typical tectonic breccias had formed.

By the types of support and discharge, the TurshsuShirlan syncline belt of mineral water is specific because deposits with similar hydrogeologic conditions are quite rare. As a result of carbon dioxide and high hydrostatic pressure from the ultra-basic formation, the ascending springs discharge.

On the schemes of tectonic zoning of the Caucasus, available in various studies conducted over many decades, its southern part was distinguished as the Araz (Nakhchivan) block of the Central Iranian microcontinent or the Araz Mega-Zone that is included in the Anatolia-Caucasian-Iranian segment of the Mediterranean Folded Belt. The aspects of geology, tectonics and fossils of the Nakhchivan region are superbly described in the monograph "Geology of the
Nakchchivan Autonomous Soviet Socialist Republic", where the scheme of tectonic zoning designates the Sharur-Julfa and Zengezur anticlinorium and the Ordubad synclinorium that divides them (Geologiya Azerbajdzhana, 2005; P1lchin and Eppelbaum, 2020).

The studies conducted in the Araz Mega Zone focusing on the proportion of the stages of the development of the region with folded structures allowed distinguishing three structural complexes that correspond to the three stages of the development of the region: 1 - Baikal - Pre Cambrian, Lower Paleozoic (along the Girratag fault); 2 - Hercynian Middle-Upper Devonian, Carbon, Permian, Triassic age; 3 - Alpine - Jurassic and Lower Cretaceous, Upper Cretaceous, Paleogene - Eocene, Oligocene age (Rustamov, 2005).

In the Middle Devonian age, the territory underwent transgression. Here the Triassic rocks are more closely related to the Paleozoic age rather than the Jurassic period. At the border between the Triassic and Jurassic deposits, there occurs a significant change in the geological conditions. There are broadly distributed volcanic formations of 1,000-3,500 m thickness (Azizbekov, 1961; Karimli, 2020). The Paleogenic rocks are broadly distributed, especially in the Nakhchivan Autonomous Republic. They are represented by alternation of clays, sands and marlstones. In the upper 
reaches of the Terter and Akara rivers, effusive rocks, tufagenic rocks, pyroclasts were observed. Along with the sedimentary deposits, the Nakhchivan Autonomous Republic has many volcanogenic formations with thickness of 1,000-3,500 and more.

The Miocene deposits in the Nakhchivan Autonomous Republic are represented by clays, marlstones, limestones, sandstones and halite, measuring up to 2,000 m thickness. The Nakhichivan Autonomous Republic in Azerbaijan Republic is located in the southwest part of the Lesser Caucasus and occupies the area of 5.5 thou $\mathrm{km}^{2}$, its natural border of which is the Araz River in the south and southwest, and the Republic of Armenia - in the northeast and northwest.

The Talysh zone is comprised by Paleogenic and Neogene rocks. The Astara anticlinorium, Lerik synclinorium, Burovar upland, Yardimli and Jalilabad synclinoriums are distinguished (Mamedov, 1999; Kerimov, 2020).

The Paleogene rocks are represented by the volcanogenic-sedimentary layer composed of tufa sandstones, tufa aleurites, clays and sandstones, and 2,000-3,000 $\mathrm{m}$ thick basalt layers. The
Neogene sediments are manifested by clays with layers of sandstones and limestones with thickness up to $1,500 \mathrm{~m}$ (Fig. 2). The following structures were distinguished - Astara anticlinorium, Lerik synclinorium, Burovar upland, Yardimli and Jalilabad synclinorium.

The Astara anticlinorium has the most complex structure and is located on the extension of the northeast wing of the Elburz folded belt. The anticlinorium is composed of tufa-sedimentary rocks of the Upper Cretaceous-Paleogene and volcanogenic rocks of the Lower and Middle Eocene. In the current erosional section, it represents two structure: the Astara Upland and Kosmolian Depression (Mamedov, 2000; Mamedov, et al., 2007).

The structure of the Lerik synclinorium includes the volcanogenic-sedimentary complex of the Upper Eocene. This synclinorium is a structure of the second row and is overlaid by the Yardimli synclinorium in the northwest, and is cut by the marginal Pre-Talysh fault in the southeast. The southwest border of the synclinorium is stretched in a straight line northeast due to the lengthwise fault (Rustamov, 1995).

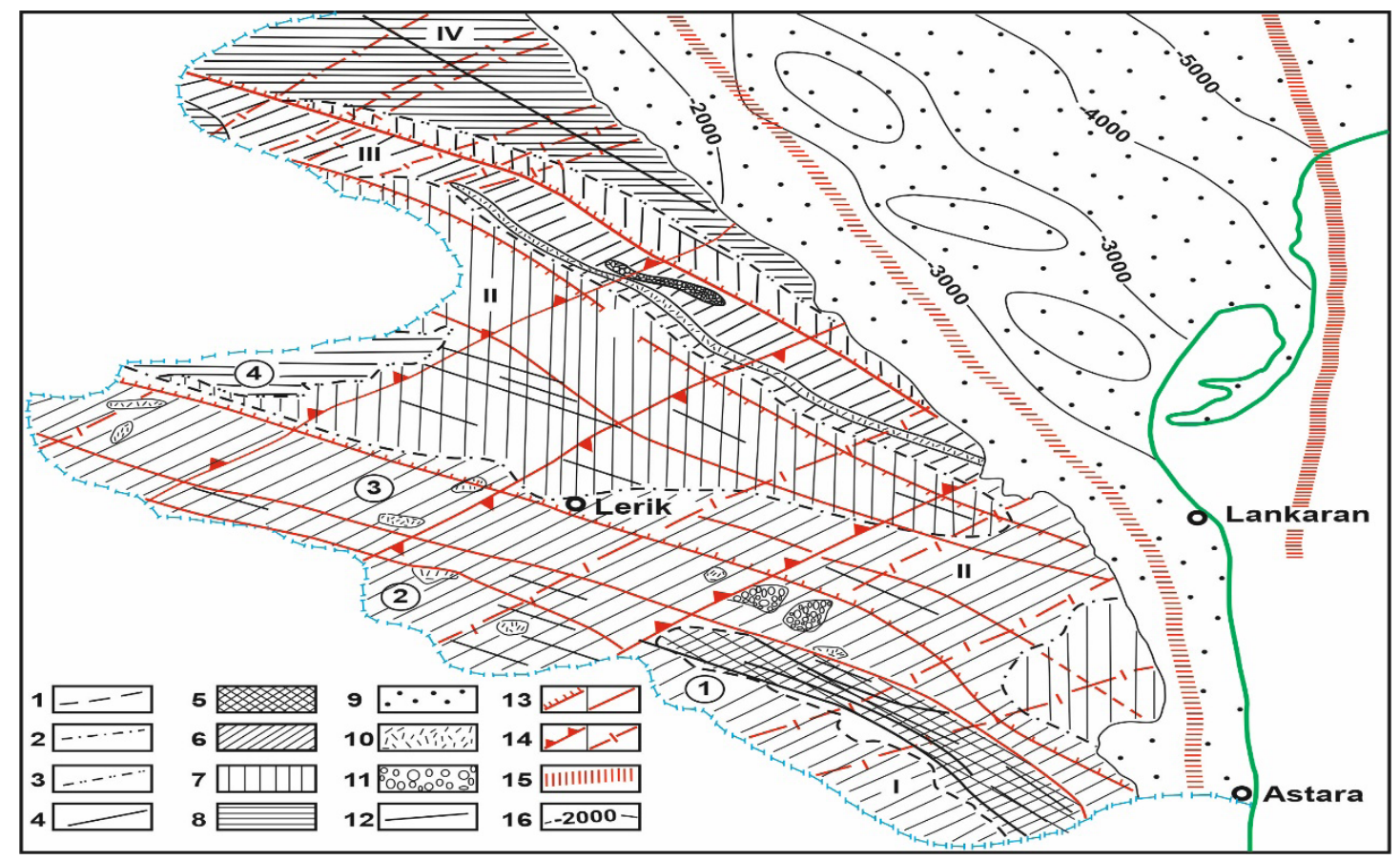

Fig. 2. Geological-tectonic map of the Talysh zone

1-4 - borders of the structural stages in the foot: 1 - Early Eocene; 2 - Early Oligocene; 3 - Middle Miocene; 4 - Pleistocene. 5-9 - formations and complexes: 5 - sedimentary-tufagenic of Upper Cretaceous-Paleogene age; 6 - volcanogenic (alkaline basaltoids) Eocene; 7 - marine molasse Oligocene-Early Miocene; 8 - lagoon-marine Middle Eocene; 9 - continental-marine quarter. 10-11 subvolcanic intrusions: 10 -Eocene; 11 - subalkaline ultrabasites; 12 -axis of the fold; 13 - faults at the borders of the tectonic zones; 14 - transversal faults (flexures); 15 - buried deep faults according to the geophysical data; 16 - isolines along the buried surface of the Upper Cretaceous deposits.

The Alaşar-Burovar anticlinorium is developed only in the northern Talysh, located between the Bolgarchay and Veravulçay rivers. The eastern wing of the anticlinorium is separated from it by the Pre-Talysh deep fault and is completely covered by Quaternary deposits. The length-wise structures of the Talysh zone have transversal faults that affect the distribution of 
sedimentary, volcanogenic and intrusive formations (Kazimova and Kazimov, 2020).

In general, the Talysh and Lankaran Lowland are characterized by mountain terrain that is rapidly descending northeast towards the Caspian Sea. Mineral waters in the eastern part of the region are identified to the chloride type, and are accompanied by hydrogen sulfide $\left(\mathrm{H}_{2} \mathrm{~S}\right)$ and methane $\left(\mathrm{CH}_{4}\right)$ in the north, whereas gas flows in the south are mostly composed of nitrogen $\left(\mathrm{N}_{2}\right)$. In the northwest part, the mineral waters contain hydrogen sulfide and sulfate and hydrocarbon. Such a distribution may be explained by geologicalstructural conditions in the area of discharge of groundwater, structural-facies relationship with the phases of volcanogenic activity, composition and facies of volcanites (Van der boon, etal., 2015; Tagiyev, et al.,2015).

Mineral-thermal waters are confined to the tectonic fractures and mostly flow from Peleogenic rocks, are represented by tufa sandstones mixed with tufa aleurolites and argillites, limestone-sandstones, limestone tufa aleurolites are covered that in some places by young analcime andesites or torn by gabbro-teschenite rocks. In the north, there is a group of highly mineralized (up to $17 \mathrm{~g} / \mathrm{l})$ hydrothermal sources of the Masalli. Their temperature reaches $64^{\circ} \mathrm{C}$, they contain chloride and sodium and calcium, are accompanied by methane and hydrogen sulfide, which is explained by their connection to the oil-bearing suites. In the central part of the region, there is a group of sources Lankaran, its waters have lower temperature and comparatively low mineralization $(3 \mathrm{~g} / \mathrm{l})$. They are mainly accompanied by nitrogen and hydrogen sulfide gases. The south group of thermal $\left(38-50^{\circ} \mathrm{C}\right)$ sources is highly mineralized $(20 \mathrm{~g} / \mathrm{l})$, followed by nitrogen of natural origin, determined by the proportion of argon and nitrogen (Tagiyev, 2001; Tagiyev, et al., 2019).

Mineral-thermal waters of all the mentioned groups are identified to chloride-sodium-calcium water, i. e. typical for oil-bearing regions, thus they need to be considered reliable criteria for the search of oil and gas in the regions adjoining this zone.

Currently, in Azerbaijan, there is active ongoing integrated work on restoration of the completely destroyed liberated areas of the Lesser Caucasus.

Taking into account the complexity of geologictectonic development of the Lesser Caucasus, predatory exploitation of dozens various fossil deposits by Armenia, the scientific and field geological surveys in the occupied regions have been practically stopped

\section{References}

Abdullaev, R.N., Mustafaev, G.V., Mustafaev, M.A., Aliev, I.A., 1988. Mezozojskie magmaticheskie formacii Malogo Kavkaza i svyazannoe s nimi endogennoe and there is a complex survey to be carried out by the geological and ecological survey of the Republic.

We have to note that over more than 30 years, the Armed Forces of Armenia have occupied not only the territory of Nagorno-Karabakh, but dozens of other districts of the so-called "buffer zone" around the Nagorno-Karabakh. Moreover, in the recent years, there have been great scientific achievements made in geology around the globe mostly due to the development of novel cosmogeological, geological, geophysical and geochemical studies.

We are glad to note that our armed forces have already liberated the occupied territories and this region is already being restored by the forces of our republic. Using modern methods, new deposits of ore, nonmetallic minerals and mineral waters will be discovered in this rich region.

A detailed inventory of the stratigraphic division of the Jurassic deposits, a biostratigraphic scheme of the Upper Cretaceous deposits should be performed, taking into account the new and highly informative methods of identification of the recent tectonic activity, detecting the tension zones, compressions and horizontal shifts, as well as renewal of surveys of the ophiolite zone of the Lesser Caucasus.

\section{Conclusions}

1. The study and assessment of various types of gold-bearing deposits, especially in the volcanic belts of the Azerbaijan part of the Lesser Caucasus, are some of the most relevant issues of extending the mineral and raw material basis of copper, gold, rare, rare-earth elements and other deposits of fossil fuels.

2. Analysis of geological materials confirms that the origin and pattern of distribution of deep tectonic faults is important in the development of geological, including volcanic- plutonic, metamorphic processes and ore development that is related to them. Currently, in the territory of the Republic, dozens of assessed and explored gold-bearing deposits are known. The greatest amount of original deposits is located in the Lesser Caucasus part of the Republic.

3. The territory of the Lesser Caucasus is divided by numerous deep tectonic faults, where volatile compounds of post-magmatic products and water vapors from migrate great depths. The presence of numerous deep tectonic faults has been noticed that hydrodynamically connect waters from fractures and fracture-veins, causing their complex mineralization, chemical and gas composition across the entire studied area.

orudenenie [Mesozoic igneous formations of the Lesser Caucasus and associated endogenous mineralization]. Baku, ed. Elm, 254 p. (In Russian). 
Azizbekov, Sh.A., 1961. Geologiya Nahchivanskoj ASSR [Geology of the Nakhchivan Autonomous Soviet Socialist Republic].M.: State. scientific and technical publishing house, 502. In Russian).

Baba-zade, V.M., 2003. Rudnye formacii i metallogenicheskie zony Azerbajdzhana [Ore formations and metallogenic zones of Azerbaijan]. Baku: National Encyclopedia of Azerbaijan, 273. (In Russian).

Geologiya Azerbajdzhana [Geology of Azerbaijan], 2001. Ed. Academician A. A. Alizade. Baku: Nafta-Press, V. 3. Magmatism, 434. (In Russian).

Geologiya Azerbajdzhana [Geology of Azerbaijan], 2005. Ed. Academician A. A. Alizade. Baku: Nafta-Press, V. 4. Tectonics, 505. (In Russian).

Imamverdiev, N.A., 2000. Geohimiya pozdnekajnozojskih vulkanicheskih kompleksov Malogo Kavkaza [Geochemistry of Late Cenozoic volcanic complexes of the Lesser Caucasus]. Baku: Nafta-Press, 192. (In Russian).

Imamverdiev, N.A., Mansurov, M.I., Salmanly, R.M., Musaev, Sh.D. 2015. Sredneyurskij ostrovoduzhnyj vulkanizm i svyazanoe s nimi zolotoe orudeneniya Chovdarskoj ploshchadi (Malyj Kavkaz, Azerbajdzhan) [Middle Jurassic island-arc volcanism and associated gold mineralization of Chovdar area (Lesser Caucasus, Azerbaijan)].Domestic geology. Moscow, 1, 43-56 (In Russian).

Imamverdiyev, Nazim, Gasanguliyeva, Minakhanym, Kerimov, Vagif, Kerimli, Ulker, 2020. Petrogeochemical features of the neogene collision volcanism of the Lesser Caucasus (Azerbaijan). Journal Geolocy, Geografy, Geoecolcy - Dnipro. 29 (2), 289-303. DOI https://doi. org/10.15421/112027

Karimli, U.I., 2020. Stadii mineralizacii i faktory lokalizacii Agyurtskogo zoloto-medno-molibdenovogo mestorozhdeniya (Malyj Kavkaz, Azerbajdzhan) [Stages of mineralization and localization factors of the Agyurt gold-copper-molybdenum deposit (Small Caucasus, Azerbaijan)].Visnyk of Kyiv University Geology, 89 (2), 96-101. (In Russian). http://doi.org/10.17721/17282713.89.13

Kazymova, S.E., Kazymov, I.E.,2020. Geodinamika Talyshskogo regiona po dannym mekhanizmov ochagov zemletryasenij i GPS stancij[Geodynamics of the Talysh region according to the data of earthquake focal mechanisms and GPS stations].Geology and geophysics of the South of Russia. 10 (3), 40-56 (In Russian). DOI: 10.46698/VNC.2020.35.39.003

Kerimov, V.M, 2020. Usloviya generacii subshchelochnyh i shchelochnyh bazal'toidnyh serij Talysha [Conditions for the generation of subalkaline and alkaline basaltoid series in Talysh].Ural Geological Journal, 3 (135), 35 43. (In Russian).

Mamedov, M.N., 1999. Petrologiya i geohimiya pozdnemelovyh i eocenovyh magmaticheskih formacij Malogo Kavkaza i Talysha [Petrology and geochemistry of the Late Cretaceous and Eocene magmatic formations of the Lesser Caucasus and Talysh]. Baku, 400. (In Russian).

Mansurov, M. I. Kalandarov, B.G., Khasaev, A.I., Takhmazova, T.G., Sattar-zade, N.A., Mamedova, A.G., Kerimov, V.M., 2018. Geologo-strukturnaya poziciya i usloviya lokalizacii Goshinskogo zoloto-kolchedannogo mestorozhdeniya (Azerbajdzhanskaya chast' Malogo Kavkaza) [Geological-structural position and localization conditions of the Gosha gold-pyrite deposit (Azerbaijan part of the Lesser Caucasus)]. Ural Geological Journal. Yekaterinburg, 6 (126), 33-47 (In Russian).

Mustafaev, G.V., Mamedov, M.N., Sadygov, N.M., Samedova, R.A., Kerimov, V.M., 2011. O zolotonosnosti paleozojskij otlozhenij fundamenta Lok-Karabahskoj tektono-magmaticheskoj zony Malogo Kavkaza [On the gold content of the Paleozoic sediments of the basement of the Lok-Karabakh tectonic-magmatic zone of the Lesser Caucasus]. Proceedings of ANAS, The Sciences of Earth, 3, 20-30 (In Russian).

Pilchin, A.N., Eppelbaum, L.V., 2020. Plate tectonics and earth evolution: a conceptual reviev. ANAS Transactions, Earth Sciences, Geology and geophysics, 2, 3-32. DOI:10.33677/ggianas20200200043

Rustamov, M.I., 1995. Tektonicheskoe polozhenie Talyshskoj skladchatoj zony v Malokavkaz- El'bursskoj sisteme [Tectonic position of the Talysh fold zone in the Malokavkaz-Elbursk system]. Proceedings of the Institute of Geology of the Academy of Sciences of Azerbaijan, 195-209 (In Russian).

Rustamov, M.I., 2005. YUzhnokaspijskij bassejn: geodinamicheskie sobytiya i processy [South Caspian basin: geodynamic events and processes]. Baku, NaftaPress, 344. (In Russian).

Tagiyev, I.I., 2001. Resursy mineral'nyh vod Azerbajdzhana [Mineral water resources of Azerbaijan]. Monogr. Baku. 320. (in Russian).

Tagiyev, I.I., Babaev, N.I., 2015.Современное состояние минеральных и термальных вод Азербайджана и концепция развития больнеологии и энергетики[Тhe current state of mineral and thermal waters of Azerbaijan and the concept of the development of balneology and energy]. Eurasian scientific association of the results of science and practice - XXII International Scientific. Conf. - Moscow, 81-86 (in Russian).

Tagiyev, I.I., Babaev, N.I., 2019. Sovremennoe sostoyanie i vozmozhnosti ispol'zovaniya mineral'nyh i termal'nyh vod Azerbajdzhana [The current state and possibilities of using the mineral and thermal waters of Azerbaijan]. Uchen. Notes of the Research Institute of Geotechnological Problems of Oil, Gas and Chemistry, Baku, 65-72 (In Russian).

Van der boon, A., Kuiper, K.F., Villa, G., Renema, W., 2015. Onset of Maikop sedimentation and cessation of Eocene arc volcanism in the Talysh Mountains, Azerbaijan. Geological Society, London, Special Publications, V. 428, 145-169. Retrieved from: https://doi.org/10.1144/ SP428.3 